\title{
KEWENANGAN PEMERINTAH DALAM PEMBENTUKAN PERATURAN KEBIJAKAN
}

\author{
Oleh :
}

Ni Luh Gede Astariyani ${ }^{1}$

\begin{abstract}
Shifting the notion countries formal law into state law meteriil (wefare staat) within the meaning of the welfare state agency or official Administrative often take a variety of specific policy measures, among others, creating what is commonly called policy rule(beleidsregel). Such products can not be separated from the association Freies ermessen. In order setting is a rule or rules of conduct set that regulation (Regeling) can be found in the legislation (Algemeen verbindende voorschriften) internal rules that apply to the (interne regelingen) and policy (beleidrege). Establishing the policy rule (beleidsregel) is located on the beoordelingsruimte (space considerations) given by the legislators to officials or governing bodies to take action on its own initiative public law that is setting, determination and positive action to resolve the problem-governance problems faced. Freis ermessen only intended use in the public interest. Freis ernessen implementation should be morally accountable to God Almighty, uphold the dignity and the degree of human dignity and the values of truth and justice, promoting unity and oneness, for the sake of joint / public interest. Tests on policy rule is more geared to doelmatigheid guided by the general principles of good governance
\end{abstract}

Keywords: Authority And Policy Rule

\section{PENDAHULUAN}

\subsection{Latar Belakang}

Pengaturan dalam konstitusi yaitu Pasal 1 ayat (3) UUD NRI 1945, bahwa Negara Indonesia adalah negara hukum mengandung yang memiliki arti luas tentang keberlakuan prinsip negara berdasarkan hukum (rechtsstaat) seperti di pada negara lain. Dalam negara hukum kesejahteraan (welfare state) dimana tugas pemerintah yang paling utama adalah memberikan pelayanan umum atau mengusahkan kesejahteraan bagi setiap warga negara, dan memberikan perlindungan bagi warga negara dalam pelaksanaan pemerintahan. Willem Koninjnenbelt, menyatakan unsure-unsur

Penulis Dosen Fakultas Hukum Universitas Udayana, email: astariyani99@yahoo.com penting gagasan tentang negara hukum yaitu:

a. kekuasaan memerintah didasarkan pada kewenangan yang diperoleh dari UUD dan atau UU (wetmatigheid van bestuur);

b. Perlindungan HAM oleh pemerintah (grondrechten);

c. Adanya pemisahan kekuasaan, yang berimbang dan saling mengawasi (machtsverdeling); dan

d. Setiap tindakan pemerintahant dikontrol oleh badan peradilan yang menilai secara bebas sahnya perbuatan tersebut (rechterlijke controle). ${ }^{2}$

Willem Konijnenbelt, 1988, Hoofdstukken van Administratief Recht, Lemma, hlm.36 - 37. 
Di dalam literatur rechtsstaat en Sturing yang ditulis oleh Bevens dinyatakan bahwa kekuasaan peme-rintah (bestuur) yang menjadi objek hukum administrasi adalah kekuasaan negara di luar kekuasaan legislatif dan yudisiil yang lebih dikenal dengan istilah bestuur. Konsep bestuur mengandung konsep sturing (sturen). Konsep sturen pada dasarnya mengandung unsur-unsur:

1) Sturen merupakan kegiatan kontiniu; kekuasaan pemerintah dalam menerbitkan izin men-dirikan bangunan dan lain-lain.

2) Sturen berkaitan dengan peng-gunaan kekuasaan; konsep keku-asaan adalah konsep hukum publik.

3) Sturen meliputi bidang di luar kekuasaan legislasi dan yudisial, namun kekuasaan ini lebih luas dari kekuasaan eksekutif.

Undang-Undang No 5 Tahun 2014 tentang Aparatur Sipil Negara mengatur tentang asas Penyelenggaraan kebijakan dan manajemen Aparatur Sipil Negara yaitu dalam Pasal 2 pada prinsipnya asas tersebut antara lain :
a. pengaturan kepastian hukum;
b. profesionalitas;
c. proporsionalitas;
d. keterpaduan;
e. delegasi;
f. netralitas;
g. akuntabilitas;
h. efektif dan efisien;
i. keterbukaan;
j. nondiskriminatif;
k. persatuan dan kesatuan;
1. keadilan dan kesetaraan; dan
m. kesejahteraan.

Dalam penyelenggaraan pemerintahan bentuk penerapan asas kepastian hukum di- laksanakan berupa penyelenggaraan kebijakan dan Manajemen ASN dengan mengutamakan landasan peraturan perundang-undangan, kepatutan, dan keadilan. Sifat aktif pemerintah seperti yang digambarkan dalam konsep sturen dimaksudkan dalam bertindak tidak terbatas pada perbuatan keputusan atau pengaturan saja melainkan ikut serta dalam perumusan kebijakan dan evaluasi kebijakan. Sturen berkaitan dengan penggunaan kekuasaan dan penggunaan kekuasaan harus dilandaskan pada azas negara hukum, azas demokrasi dan azas instrumental. Azas negara hukum berkaitan dengan azas wet en rechtmatig van bestuur. Azas demokrasi berkaitan dengan azas keterbukaan dan tidak sekedar adanya badan perwakilan rakyat, tetapi juga memberikan kesempatan kepada masyarakat untuk berperan serta dalam pengambilan keputusan. Azas instrumental berkaitan dengan hakekat hukum administrasi sebagai instrumen. Dalam kaitan ini azas efektifitas (doeltreffenheid: hasil guna) dan efisiensi (doelmatigheid: daya guna) harus diperhatikan dalam pelaksanaan pemerintahan.

Kekuasaan pemerintahan tidak hanya sebagai kekuasaan terikat melalui prinsip wetmatigheid saja, tetapi dalam batas tertentu memiliki ruang diskresi tidak murni. Diskresi murni merupakan kebebasan untuk memutuskan secara mandiri. Sedangkan diskresi tidak murni adalah kebebasan untuk melakukan inter-pretasi terhadap ketentuan norma hukum yang samar-samar. Untuk menjangkau kekuasaan diskresi di beberapa negara dewasa ini dalam kaitan dengan rechtmetigheid van bestuur dikembangkan asas-asas umum pemerintahan yang baik dalam penyelenggaraan pemerintahan. Asasasas pemerintahan yang baik tersebut apabila 
dikaitkan dengan asas-asas penyelenggaraan negara dalam Undang-Undang No 28 Tahun1999 yang oleh Penjelesan Pasal 53 ayat (2) UU PTUN Tahun 2004 disamakan dengan asas-asas umum pemerintahan yang baik, disebutkan bahwa asas umum penyelenggara negara yang baik adalah asas yang menjunjung tinggi norma kesusilaan, kepatutan dan norma hukum, untuk mewujudkan penyelenggara negara yang bersih dan bebas dari korupsi kolusi dan nepotisme. Pada prinsipnya asas-asas umum pemerintahan yang baik yaitu asas-asas hukum yang harus diperhatikan oleh para penyelenggara negara. ${ }^{3}$ Apabila diasumsikan hukum administrasi adalah pemerintahan yang sah, maka azas keabsahan dalam pemerintahan memiliki 3 fungsi yaitu :

1. Untuk penyelenggara pemerintahan azas keabsahan berperan sebagai dasar hukum penyelenggaraan pemerintahan (bestuurs-normen);

2. Untuk penerapannya bagi yang dikenai pengaturan azas keabsahan berfungsi sebagai alasan peng-ajuan gugatan terhadap tindak pemerintahan (beroepsgronden); dan

3. bagi lembaga peradilan (hakim) azas keabsahan berfungsi sebagai dasar pengukian suatu tindak pemerintahan (toetsingsgronden).

\subsection{Rumusan Masalah}

Dengan mengkaji pada asas negara hukum dan kekuasaan pemerintah maka dalam negara hukum segala tindakan di dasarkan atas hukum, karena teori negara

I Nyoman Suyatna, 2011, Ringkasan Disertasi : Asas-asas Umum Pemerintahan Yang Baik Dalam Pembentukan Peraturan Daerah, Program Studi Doktok Ilmu Hukum Fakultas Hukum Universitas Brawijaya, Malang, hlm.39. hukum didasarkan atas asas legalitas, apakah dalam negara hukum pemerintah dapat membuat kebijakan.

\section{Metode Penelitian}

Penulisan ini menggunakan jenis penelitian hukum normatif dengan pendekatan konsep, pendekatan histories, pendekatan filsafat, pendekatan kasus dan pendekatan kontekstual terkait penerapan hukum. Dalam penelitian hukum normative menggunakan sumber bahan hukum yang digunakan adalah bahan hukum primer dan bahan hukum sekunder.Metode Pengumpulan Bahan Hukum dengan studi dokumentasi. Analisis Bahan Hukum dalam kajian ini adalah teknik menggunakan teknis analisis deskripsi, interpretasi dengan berpedoman pada paradigma interpretivisme, sistematisasi, argumentasi dan evaluasi.

\section{HASIL DAN PEMBAHASAN}

\subsection{Kewenangan Pemerintah Dalam Tata Pengaturan}

A. Hamid S. Attamimi di dalam pidato purna bakti yang berjudul Hukum Tentang Peraturan Perundang-undangan dan Peraturan Kebijakan (Hukum Tata Pengaturan) mengunakan istilah tata pengaturan pertama kali . Dalam kaitannya dengan tata pengaturan : Tata berarti aturan, susunan, sistem. ${ }^{4}$ peraturan, cara. Pengaturan berarti proses, cara, perbuatan mengatur. ${ }^{5}$ Maka dapat disimpulkan pengertian tata pengaturan adalah suatu aturan atau kaidah tentang perbuatan mengatur yang bentuk pengaturannya(regeling) dapatdijumpaipada

W.J.S.Poerwadarminta, 2003, Kamus Umum Bahasa Indonesia, Edisi Ketiga, Balai Pustaka Jakarta, hlm.1024.

Ibid, hlm.65. 
peraturan perundang-undangan (algemeen verbindende voorschriften) peraturan intern yang berlaku ke dalam (interne regelingen) dan peraturan kebijakan (beleidrege).

Pengaturan (regeling) memiliki makna lebih luas dari pada peraturan perundangundangan (wetgeving) dan keputusan (beschiking) Dalam tata pengaturan yang menjadi bagiannya adalah Peraturan Perundang-undangan dalam Konteks Hukum Tata Negara dan Peraturan Kebijakan yang masuk dalam Hukum Administrasi Negara. Attamimi menyatakan tata pengaturan mencakup semua jenis peraturan perundangundangan yang memang merupakan satu rangkaian yang berkaitan semua peraturan kebijakan yang seringkali format, bentuk serta daya ikatnya dirasakan masyarakat tidak berbeda dengan peraturan perundangundangan. ${ }^{6}$

Dalam kaitannya dengan fungsi-fungsi negara Van Vollenhoven yang membagi atas empat fungsi (catur praja) yaitu regeling (pengaturan), bestuur ( pemerintah dalam arti sempit ketataprajaan), politie (keamanan), dan rechtspraak (peradilan). ${ }^{7}$ Fungsi bestuur, politie, rechtspraak dewasa ini telah berkembang menjadi bestuursrecht, politierecht, rechtspraaksrecht nampaknya fungsi regeling belum menjadi regelingrecht. Dilihat dari kewenangan pembentukan pengaturan dalam suatu negara terhadap warga negara dan penduduk secara umum (dari segi adresssat) dan secara abtsrak (dari yang diatur) beserta ketentusn sanksi

A.Hamid.S.Attamimi Attamimi, A.Hamid S. 1993 , Hukum tentang Peraturan Perundang-undangan dan Peraturan Kebijakan (Hukum Tata Pengaturan), Pidato Purna Bahakti Guru Besar Tetap Fakultas Hukum Universitas Indonesia, hlm.17.

Diana Halim Koentjoro, 2004, Hukum Adminitrsi Negara, Ghalia Indonesia, hlm 17. pemaksa dan sanksi ketentuan pidana, pada hakekatnya dalah fungsi legislative yang bersumber pada volunte generale. Pemerintah yang dapat berwujud raja atau penguasa merupakan lembaga perantara antara rakyat dan negara dan bertugas melaksanakan peraturan tersebut. Hanya dalam perkembangannya yang datang kemudian pelaksanaan fungsi reglementer dan berdasarkan fungsi eksekutif didasarkan pada peraturan negara yang lebih tinggi dalam wujud kewenangan atribusi dan delegasi, oleh karena itu dilihat dari fungsi pengaturan oleh negara ( staatliche rectssetzung) diperlukan adanya suatu tata pengaturan. Dalam tata pengaturan tentunya harus dilihat dari apa permasalahannya. Adanya kelompok yang beranggapan bahwa hukum yang mengatur kewenangan tersebut dan atribusi serta delegasinya termasuk dalam Hukum Tata Negara. Ada pula yang berpendapat bahwa hukum yang mengatur keputusan dalam arti umum (besluiten) termasuk keputusan (besluit) pembentukan undang-undang ke dalam Hukum Administrasi Negara, akan memasukkan Hukum Tata Pengaturan ke dalam Hukum Administrasi Negara. Namun ada yang berpendapat bahwa hukum yang mengatur kehidupan kenegaraan perlu dibagi. Untuk menelaah dalam konteks HAN dan pengembangannya dewasa ini di Indonesia. Tetapi sebelum menelaah dalam konteks HAN tersebut, secara garis besar perlu disinggung beberapa pengertian tentang negara misalnya Negara Hukum (rechtstaat), Negara Nasional (nasional statae), Negara Territorial Modern (modern territorial state) dan mengenai Kekuasaan Negara (public power) dalam pembagian atau pendelegasian serta kebijaksanaan negara ( public policy) yang mempengaruhi perkembangan HAN. 
Menurut pendapat Heinz Schaffer yang dikutip oleh Attmimi menyatakan bahwa masalah-masalah teoritis dan praktis tentang ilmu pembentukan hukum (rechtssetzungslehre) tidaklah hanyameliputi pembentukan undang-undang ( gezet) dalam arti formal semata-mata, melainkan juga meliputi pembentukan seluruh peraturan yang berlaku umum. ${ }^{8}$ Menurut pendapat Van der Vlies yang dikutip oleh Attamimi dalam disertasinya mengemukakan pengaturan (regeling) ialah dalam bentuk peraturan perundang-undangan (algemeen verbindende voorschriften), peraturan intern yang berlaku ke dalam bagi lembaga penyelenggara (interne regelingen), dan peraturan kebijakan (beleidregels).

Menurut Jimly Asshiddiqie terdapat empat kategori peraturan tertulis yang penting mendapat perhatian yaitu :

1). Bentuk peraturan perundang-undangan yang umum, memiliki keberlakuan umum, bersifat abstrak, karena tidak menunjuk kepada hal kongkret yang sudah ada sebelum peraturan itu ditetapkan ;

2). Bentuk Peraturan perundang-undangan yang khusus karena subyek yang diaturnya, yaitu dengan keberlakuan bagi subyek hukum tertentu;

3). Bentuk Peraturan perundangundangan yang khusus karena wilayah berlakunya wilayah lokal tertentu ;

4). Bentuk Peraturan perundang-undangan yang khusus karena daya ikat materinya berlaku internal. ${ }^{9}$

Bentuk dan jenis pengaturan tertulis yang dikenal dengan peraturan atau "regels,

A. Hamid.S.Attamimi Attamimi, op.cit, hlm.18.

A.Hamid.S.Attamimi Attamimi,1993, op.cit, hlm.18. regulations dan legislatin" dan bentukbentuk statutory instruments lainnya sangat beranekaragam. Bahkan ada pula dalam bentuk tertentu sebagai policy rules atau beleidregels dalam bentuk peraturan kebijakan dan bukan peraturan perundangundangan. Keanekaragaman peraturanperaturan itu yang merupakan tata pengaturan keberadaannya sangat tergantung pada :

1). Tingkatan kepentingan ;

2). Relevansi materi muatan yang hendak diaturnya ;

3). Lembaga atau organ jabatan kenegaraan dan pemerintahan yang diberiwewenanguntukmenetapkannya menjadi peraturan.

Dalam

penyelenggraaan

pemerintahan negara terdapat dua jenis peraturan yang berlaku secara berdampingan yaitu peraturan perundang-undangan dan peraturan kebijakan.

Mengingat kedudukan badan administrasi negara sedemikian penting dan menentukan, maka peraturan kebijakan dalam bentuk peraturan maupun dalam bentuk keputusan baik di pusat maupun di daerah yang berfungsi pengaturan. Fungsi pengaturan adalah bagian yang essensial dari Negara Republik Indonesia sebagai negara hukum sosial ( sociale rechtstaat), dalam arti bahwa sociale rechtstaat itu tidak mungkin mencapai tujuan atau tidak mungkin menjadi kenyataan tanpa adanya tata pengaturan dalam bentuk peraturan kebijakan yang merupakan perwujudan kebebasan bertindak oleh Pejabat Tata Usaha Negara berdasarkan wewenang tidak terikat. Apabila diperhatikan pandangan tersebut, maka kenyataannnya dalam praktik pemerintahan daerah, nampaknya peraturan kebijakan dewasa ini, banyak yang bersifat 
mengatur dan bahkan mengikat warga secara umum. Hal ini merupakan masalah karena badan atau pejabat yang mengeluarkan keputusan tidak memiliki kewenangan untuk mengatur, lebih-lebih untuk mengikat warga secara umum.

Tugas pemerintahan tidak hanya menerapkan ketentuan yang tertulis dalam dalam pengaturan karena pembuat hukum tidak akan mamapu memperhitungkan situasi kongkrit yang timbul dalam penerapannya. Pergeseran pemikian negera hukum formil menjadi negara hukum meteriil ( wefare staat) tidak mungkin segala sesuatu ditur dalam peraturan perundang-undangan dengan kompleksnya tugas pemerintah, badan pemerintah yang dilakukan pemerintah, badan-badan pembuat undangundang berkecendrungan memberikan lebih banyak kebebasan untuk melaksanakan pemerintahan. ${ }^{10}$

\subsection{Peraturan Kebijakan}

Penyelenggaraankebijakanpemerintah merupakan penentuan kebijakan dalam pembangunan dan kesejahteraan masyarakat yang diarahkan untuk peningkatan pelayanan dan pemberdayaan dalam rangka penyelenggaraan kepentingan umum kesejahteraan masyarakat.

Pemerintah dalam melaksanakan tugas-tugas pemerintahan dibebankan oleh pembentuk Undang-undang seringkali terjadi, bahwa tindakan pelanggaran berupa kebijakan dalam bentuk peraturan yang ditujukan kepada masyarakat. Peraturan tersebut terjadi tanpa mempunyai wewenang membuat peraturan. Gejala ini tidak

\footnotetext{
10 Philipus M Hadjon, 1988, PengertianPengertian dasar Tentang Tindak Pemerintahan (Besturhandeli),hlm.44.
}

dapat dikatakan sebagai bentuk Peraturan Perundang-undangan, sedangkan ditinjau dari fungsi atau materi muatannya mirip dengan Peraturan Perundang-undangan.

Dalam kaitannya dengan pengatribusian dan pendelegasian A.Hamid. S.Attamimi mengemukakan :

Selain jenis dan bentuk peraturan perundang-undangan yang dibentuk berdasarkan fungsi legislative, diperlukan bagi penyelengara kebijakan pemerintahan yang tidak terikat (vrijbeleid) pun tentunya akan dikeluarkan juga berbagai peraturan kebijakan (beleidsregel) yang diadasrkan pada kewenangan eksekutif. ${ }^{11}$

Peraturan kebijakan (beleidsregel) terjadi dalam bentuk yang berlainan, melakukan pemerintah yang bebas ( tidak terikat). Penyelenggaraan pemerintahan yang tidak terikat ini memberi kesempatan bebas bagi fungsi pengaturan secara administratif akibatnya dapat dibayangkan betapa banyaknya peraturan perundang-undangan dan peraturan kebijakan yang belum tentu semuanya memenuhi syarat asas perundangundangan dan asas kebijakan yang patut. Dengan demikian maka dalam praktik penyelenggaraan pemerintahan terdapat jenis peraturan yang dapat berlaku secara berdampingan, yaitu peraturan perundangundangan dan peraturan kebijakan. Kedua jenis peraturan perundang-undangan itu dalam kenyataan tidak mudah untuk dibedakan dan disamakan. Badan atau Pejabat Tata Usaha Negara sebagai penentu kebijakan dewasa ini seringkali melakukan tindakan-tindakan berupa keputusan yang

11 A.Hamid S. Attamimi, 1993, op.cit, hlm.5. 
tidak memenuhi syarat menurut hukum sama sekali sehingga muncul dalih fries ermessen dan demi kepentingan umum atau pembangunan. Untuk menghindari dan mengantisipasi hal tersebut perlu diupayakan agar peraturan kebijakan memenuhi syaratsyarat asas pemerintahan yang baik dan patut.

Dapat disimpulkan bahwa yang berdasarkan kebebasan bertindak dapat mempunyai kekuatan mengikat sebagai :

1. Memiliki kekuatan mengikat apabila pembentukannya berdasarkan kewenangan delegasi suatu undangundang.

2. Apabila pembentukannya berasal dari kebebasan penilaian atau kebebasan interpretasi.

\subsubsection{Dasar Pembuatan.}

Menurut Belifante peraturan perundang-undangan semu adalah :

Tindakan hukum administrasi yang bukan merupakan peraturan umum yang mengikat yang timbul menurut peraturan untuk itu dalam Hukum Tata Negara atau ditetapkan oleh badan yang dinyatakan berwenang, dalam Hukum Tata Negara untuk perundangundangan dalam arti material, melainkandalambentuk kebijaksanaan yang bentuk penerapannya dalam bidang hukum administrasi ${ }^{12}$

Peraturan kebijakan (beleidsregel) dibentuk sebagai perwujudan Fries Ermessen (discretionary power) yaitu kewenanagan

Johanes Usfunan, 2002, Perbuatan pemerintah yang dapat Digugat, Djambatan, Jakarta, hlm.109. yang berkarakter Fries Ermessen dalam bentuk tertulis dan mengikat pada warga. Materi muatan pengaturannya memuat aturan umum (algemene regel) tersendiri yang melampaui cakupan kaidah ( materialsphere) peraturan perundang-undangan yang dibuat pengaturan secaraoperasional.Lembaga yang membuat peraturan kebijakan (beleidsregel ) tidak memiliki kewenangan membentuk perundang-undangan namun secara tidak langsung mengikat para warga sebagaimana halnya dengan kaidah-kaidah " juridische regels". Dapat disimpulkan bahwa bentuk peraturan kebijakan bukanlah peraturan perundang-undangan. Karena lembaga yang membentuk peraturan kebijakan tidak memiliki kewenangan pembuatan peraturan perundang-undangan (wetgevende bevoegdheid). Bentuk peraturan kebijakan tidak langsung mengikat secara hukum, tetapi mempunyai relevansi hukum.

Pembentukan peraturan kebijakan (beleidsregel) didasarkan pada adanya beoordelingsruimte (ruang pertimbangan) agar mengambil tindakan hukum publik yang bersifat pengaturan yang diberikan pembentuk undang-undang kepada pejabat atau badan-badan pemerintahan atas inisiatif sendiri. Inisiatif ini berupa tindakan nyata yang positif guna menyelesaikan masalahmasalah penyelenggaraan pemerintahan yang dihadapi pada saat tertentu yang memerlukan pengaturan .

Ruang pertimbangan (beoordeling sruimte) dikenal ada 2 bentuk yaitu subjectieve beoordelingsruimte dan objectieve beoordelingsruimte. Subjectieve beoordelingsruimte mengandung pengertian ruang pertimbangan yang bersifat umum dan bebas semata-mata berdasarkan pertimbangan subyektif. Istilah lain dari 
subjectieve beoordelingsruimte adalah beoordelingsvrijheid, discretionaire bevvoeghdheid, freies ermessen dan beleidsvrijheid.

Objectieve

beoordelingsruimte mengandung pengertian adanya ruang pertimbangan yang bersifat interprestasi yang diberikan pembentuk undang-undang kepada pejabat atau Badan Administrasi Negara untuk melaksanakan tindakan hukum publik menurut situasi kondisi dan obyek permasalahan yang obyektif. Ruang pertimbangan yang diberikan oleh pembentuk undang-undang umumnya hanya dengan criteria yang samarsamar.. ${ }^{13}$

Peraturan kebijakan yang dibentuk didasarkan atas kebebasan bertindak harus diberi limit / batas atau tolak ukur, apapun bentuk kebebasan yang akan dipergunakan hendaknya harus ada ruang yang diberikan oleh pembentuk undangundang sehingga wewenang untuk bebas bertindak, sehingga tidak terjadi penyalah gunaan wewenang atau sewenang-wenang. Penerapan asas kebebasan bertindak dalam peraturan kebijakan merupakan bentuk sikap tindak organ pemerintahan. Menurut J.B.J. M. Ten Berrge adalah bentuk kebebasan yang diizinkan / dibolehkan oleh peraturan perundang-undangan bagi organ pemerintahan untuk membentuk keputusan dapat dibedakan dalam kebebasan kebijaksanaan dan kebebasan penilaian, yaitu :

1. Dalambentukkebebasankebijaksanaan dalam bentuk(wewenang diskret dalam arti sempit) bila Peraturan Perundang-

Lukman,Marcus 1997, Eksistensi Peraturan Kebijakan Dalam Bidang Perencanaaan Dan Pelaksanaaan Rencana Pembangunan Di Daerah Serta Dampak Terhadap Pembangunan Materi Hukum Tertulis Nasional, Disertasi UNPAD Bandung, hlm. 187-189. undangan memberi kesempatan kepada organ pemerintahan wewenang tertentu, sedangkan organ bebas untuk (tidak) menggunakannya meskipun syarat-syarat bagi penggunaannya secara sah dipenuhi ;

2. Dalam bentuk kebebasan penilaian (wewenang diskret) dalam arti yang tidak sesungguhnya) ada, menurut hukum diserahkan kepada organ pemerintahan untuk menilai secara mandiri dan eksklusif apakah syaratsyarat bagi pelaksanaan wewenang secara sah telah terpenuhi sehingga dibentuk pengaturan dalam bentuk peraturan. ${ }^{14}$

Ann Seidman dalam bukunya Penyusunan Rancangan Undang-Undang Dalam Masyarakat Yang Demokratis menyatakan pembatasan dalam pembentukan Peraturan Kebijakan : ${ }^{15}$

1. Adanya batas kewenangan yang diberikan dalam undang-undang utama pada instansi yang membentuk peraturan ;

2. Pembenutkan peraturan Tidak dibenarkan adanya pertentangan denganPeraturanPerundang-undangan lainnya ;

3. Adanya keharusan untuk memenuhi ketentuan-ketentuan dalam hhukum administrasi negara .

Dalam pembentukan peraturan kebijakan menurut Sjachran Basah menyatakan adanya pembatasan keleluasan dalam menentukan kebijakan dengan dua

4 J.B.J.M.Ten Berge, et al, 1991, Pengantar Hukum Peizinan, disunting oleh Philipus M.Hadjon, Utrecht, hlm.8.

15 Seidman, Ann et.all, 2001, Penyusunan Rancangan Undang-Undang Dalam Masyarakat Yang Demokratis, Terjemahan ELIPS Jakarta hlm.374. 
batas yaitu adanya pembatasan batas atas dan pembatasan dalam bentuk batas bawah. Batas atas adalah adalah ketaat asasan ketentuan perundang-undangan berdasarkan asas taat asas yaitu bentuk pengaturan yang berederajat lebih rendah tidak boleh bertentangan dengan peratura yang lebih tinggi. Batas bawah adalah peraturan yang dibuat tidak boleh melanggar hak dan kewajiban asasi manusia ${ }^{16}$.

\subsubsection{Karakteristik Peraturan Kebijakan}

Van Kreveld mengemukakan, peraturan kebijakan umumnya mempunyai ciri-ciri berikut :

a. Bentuk peraturan itu baik secara langsung maupun tidak tanpa ada dasar kewenangan dari UndangUndang Dasar atau pada Undangundang;

b. Peraturan itu dapat :

(1). Dalam bentuk tidak tertulis dalam bentuk rangkaian keputusan instansi pemerintah yang berdiri sendiri untuk menyelenggarakan kewenangan pemerintahan yang tidak terikat ;

(2). Ditetapkan dalam bentuk tertulis oleh suatu instansi pemerintah.

c. Bentuk pengaturan untuk bertindak dalam menyelenggarakan kewenangan pemerintahan yang tidak terikat ${ }^{17}$

Karakter dan ciri menunjukkan peraturan kebijakan bukan Peraturan Perundang-undangan. Dilihat dari segi sifat materi Peraturan Kebijakan menurut Ten Berge :

Sjahran Basah, 1992, Perlindungan Hukum terhadap Sikap Tindak administrasi Negara, Alumni Bandung, hlm.3-5.

17 A.Hamid.S.Attamimi I, op.cit, hlm.11.
"Peraturan Kebijakan (beleidsregel) hanya bisa timbul bila wewenangwewenang pemerintahan tidak terikat secara mutlak. Peraturan Kebijakan dalam praktek pemerintahan, ... melalui aturan-aturan kebijakan diberi isi pada norma-norma yang hendak ditetapkan guna kepentingan perlindungan.Aturan-aturan kebijakan diberi isi norma-norma yang hendak ditetapkan guna kepentingan perlindungan. Aturan-aturan kebijakan tidak bersandar pada suatu wewenang umum yang ditarik dari pendelgasian sehingga bukan merupakan bentuk pengaturan. Suatu konsekuensi penting dari hal ini adalah bahwa warga ( masyarakat ) tidak dapat diikat oleh aturan-aturan kebijakan. Namun organ pelaksana memang mengikat diri sendiri." ${ }^{\prime 18}$

H.M.Laica marzuki mengemukakan unsur-unsur peraturan kebijakan antara lain: 1. Dikeluarkan oleh pejabat pemerintah sebagai bentuk fries ermessen dalam pengaturan, yang setelah itu diumumkan keluar guna diberlakukan kepada warga ;

2. Materi muatan dimaksud pada nyatanya telah merupakan peraturan umum (generale rule) tesendiri, jadi tidak lagi sekedar sebagai petunjuk pelaksanaan operasional sebagaimana tujuan semula dari peratuan kebijakan itu sendiri ;

3. Badan atau pejabat itu, sama sekali tidak memiliki kewenangan membuat peraturan umum (generale rule)

18 J.B.J.M.Ten Berge, op.cit, hlm.41. 
sedemikian, namun tetap dipandang ligimated mengingat peraturan kebijakan atau beleidregel dimaksud tidak lain dari perwujudan fries ermessen yang diberi bentuk tertulis. ${ }^{19}$ Pada subjectieve beoordelingsruimte atau ruang pertimbangan bebas disebut juga dengan istilah boordelingvrijheid. Terdapat tiga boordelingvrijheid dan tiga beleidsregel yaitu :

(1). Binnen - wettelijke boordelingvrijheid yaitu peraturan kebijakan yang lahir dari kebebasan mempertimbangkan intra legal.

(2). Buiten-wettelijke boordelingvrijheid yang melahirkan kebebasan pertimbangan ekstra legal. Tidak memiliki landasan undang-undang ataupun Peraturan Perundangundangan yang jelas, alasan pembenarnya semata-mata ditekankan pada asas doelmatigheid, kebiasaankebiasaan administrasi dan asas-asas pemerintahan yang layak ;

(3) Tengen-wettelijke boordelingvrijheid yang melahirkan kebebasan pertimbangan kontrak legal. Tengenwettelijke boordelingvrijheid dibagi lagi menjadi. :

(a). Tengen-wettelijke beleidsregel yang pembentuk kannya didasarkan pada Binnen-wettelijke boordelingvrijheid yaitu peraturan kebijakan yang menyimpangi peraturan perundang-undangan yang memiliki landasan yuridis yang jelas;

19 H.M. Laica Marzuki, 1996, Peraturan Kebijakan (beleidregel), bahan penataran hukum administrasi dan hukum lingkungan, FH Univ. Airlangga Surabaya 4-12 Januari, hlm.1. (b). Tengen - wettelijke beleidsregel yang pembentukkannya di dasarkan atas bestuurbevoegdheid yaitu peraturan kebijakan yang menyimpangi Undang-undang atau Peraturan Perundang-undangan yang tidak memiliki landasan yuridis yang jelas. ${ }^{20}$

\subsubsection{Landasan Keabsahan dalam}

\section{Pembentukan.}

Pembentukan peraturan kebijakan apabila dikaji dari landasan keabsahan mempunyai nilai keadilan dan kemanfaatan keberlakuan peraturan kebijakan yang ditetapkan oleh pejabat atau badan administrasi untuk memberikan arahan bagi bawahan serta mengatur berbagai kepentingan dan posisi hukum dalam masyarakat. Peraturan kebijakan tidak memiliki nilsi kepastian hukum karena tidak ada dasar kewenangan pembentukan peraturan perundang-undangan melainkan perwujudan Fries Ermessen (discretionary power).

Penggunaaan freies Ermessen sehubungan dengan pengaturan operasional yang ada awalnya Raja menyusun garisgaris besar sebagai petunjuk ke dalam sebagai permulaan langkah untuk mencegah kebijakasanaan yang berubah-ubah tidak menentu, yang kemudian garis-garis besar kebijakan itu dipublikasikan. Peraturan Kebijakan tidak engikat langsung secara hukum tetapi memiliki relevansi hukum dan ditujukan kepada badan atau Pejabat Administrasi Negara sendiri. Penerapan freis ernessen hanya ditujukan bagi kepentingan umum. Freis ernessen tersebut harus dapat

20 Marcus Lukman, 1997, op.cit, hlm. 190-196. 
dipertanggungjawabkan secara moral kepada Tuhan Yang Maha Esa, mengutamakan persatuan dan kesatuan, demi kepentingan bersama, menjunjung tinggi harkat dan derajat martabat manusia serta nilai-nilai kebenaran dan keadilan,Pengujian terhadap peraturan kebijakan lebih diarahkan kepada doelmatigheid dan arena batu ujinya adalah asas-asas umum penyelenggaraan pemerintahan yang layak.

\section{PENUTUP}

\subsection{Simpulan}

Penyelenggara pemerintahan tidak hanya menerapakan ketentuan dalam bentuk pengaturan yang lebih tinggi karena pembentuk peraturan perundang-undangan tidak akan mamapu memperhitungkan situasi kongkrit yang timbul dalam penerapannya. Pergeseran pemikian negera hukum formil menjadi negara hukum meteriil (wefare staat) dalam arti negara kesejahteraan mengaharuskan pemerintah selaku penyelenggara pemerintahan seringkali menempuh berbagai bentuk kebijakan dengan membentuk pengaturan berupa peraturan kebijakan (beleidsregel, policy rule). Pembentukan peraturan kebijakan tidak terlepas dari penerapan freies ermessen. Dalam tata pengaturan kaidah tentang perbuatan mengatur yang pengaturannya (regeling) dalam bentuk peraturan perundang-undangan (algemeen verbindende voorschriften ) peraturan intern yang berlaku ke dalam (interne regelingen) dan peraturan kebijakan (beleidregel).

Pembentukan peraturan kebijakan (beleidsregel) diadasrkan pada adanya beoordelingsruimte (ruang pertimbangan) yang diberikan pembentuk undangundang kepada pejabat atau badan-badan pemerintahan dengan inisiatif sendiri mengambil tindakan hukum publik berupa , penetapanmaupuntindakannyatayang positif pengaturan guna menyelesaikan masalahmasalah penyelenggaraan pemerintahan yang dihadapi pada saat tertentu .

Freis ernessen ditujukan demi kepentingan umum dan harus dipertanggungjawabkan secara moral kepada Tuhan Yang Maha Esa, mengutamakan persatuan dan kesatuan, menjunjung tinggi harkat dan derajat martabat manusia serta nilai-nilai kebenaran dan keadilan, demi kepentingan bersama / kepentingan umum. Bentuk pengujian terhadap peraturan kebijakan lebih diarahkan kepada aspek kemanfaat (doelmatigheid) dengan berpedoman pada asas-asas umum penyelenggaraan pemerintahan yang baik

\section{DAFTAR PUSTAKA}

A.Hamid.S.Attamimi, 1993, Hukum Tentang Perundang-Undangan Dan Peraturan Kebijakan (Hukum Tata Pengaturan), Pidato Purna Bahakti Guru Besar Tetap Fakultas Hukum Universitas Indonesia.

Basah, Sjahran 1992, Perlindungan Hukum Terhadap Sikap dan Tindak Administrasi Negara, Alumni Bandung.

Berge J.B.J.M.Ten Splet, et al, 1991, Pengantar Tentang Hukum Peizinan, Utrecht.

Diana Halim Koentjoro, 2004, Hukum Adminitrsi Negara, Ghalia Indonesia.

Hadjon, Philipus M 1988, Pengertian Dasar Tentang Tindak Pemerintahan (Besturhandeling).

Marcus, Lukman 1997, Eksistensi Tentang Peraturan Kebijakan Dalam Bidang 
Perencanaaan Dan Pelaksanaaan

Rencana Pembangunan Di Daerah

SertaDampakTerhadapPembangunan

Materi Hukum Tertulis Nasional,

UNPAD Bandung.

Marzuki, H.M. Laica 1996, Peraturan

Kebijakan (beleidregel), bahan penataran hukum administrasi dan hukumlingkungan, FHUniv. Airlangga Surabaya 4 -12 Januari, hlm. 1.

Suyatna,INyoman2011,RingksssnDisertasi: Asas-asas Umum Pemerintahan Yang Baik (AAUPB) Dalam Pembentukan Peraturan Daerah, Program Studi Doktok Ilmu Hukum Fakultas Hukum Universitas Brawijaya, Malang.

Ann Seidman, et.all, 2001, Penyusunan Rancangan Undang-Undang Dalam Masyarakat Hukum Yang Demokratis, Terjemahan ELIPS Jakarta

Usfunan, Johanes 2002, Perbuatan Pemerintah Yang Dapat Digugat, Djambatan, Jakarta.

W.J.S.Poerwadarminta, 2003, Kamus Umum Bahasa Indonesia, Balai Pustaka Jakarta.

Willem \& Konijnenbelt, 1988, Hoofdstukken van Administratief Recht, Lemma

Undang-Undang Dasar Negara Republik Indonesaia Tahun 1945

Undang-Undang Nomor 28 Tahun 1999 tentang Penyelenggaraan Negara Yang Bersih dan bebas dari Korupsi, Kolusi dan Nepotisma

Undang-Undang Nomor 9 Tahun 2004 tentang Perubahan Atas UndangUndang No 5 Tahun 1986 tentang Peradilan Tata Usaha Negara

Undang-Undang No 5 Tahun 2014 tentang Aparatur Sipil Negara. 